\title{
natureouTLOOK
}

\section{GENE THERAPY}

13 December 2018 / Vol 564 / Issue No 7735

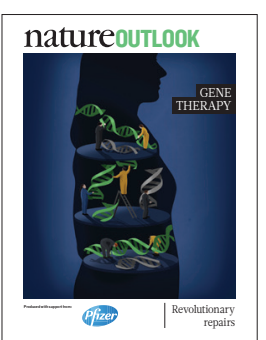

Cover art: Sam Falconer

\section{Editorial}

Herb Brody, Richard Hodson, Elizabeth Batty, Lewis Packwood, Nick Haines

Art \& Design Mohamed Ashour, Wesley Fernandes, Kate Duncan

Production Nick Bruni, Karl Smart, lan Pope Sponsorship David Bagshaw, Jay Berfas, Anushree Roy

Marketing Nicole Jackson

Project Manager Rebecca Jones

Creative Director Wojtek Urbanek

Publisher Richard Hughes

Editorial Director Stephen Pincock Magazine Editor Helen Pearson

Editor-in-Chief Magdalena Skipper
$\mathrm{P}$ harmaceuticals cannot always fix a malfunctioning human body. Sometimes the only way to treat what ails a person is to tinker with their genes: the blueprints for how biological systems are built and how they operate. Some researchers are using gene-editing techniques such as CRISPR to precisely alter DNA sequences. Others are genetically modifying immune cells to imbue them with the ability to fight cancer. And in the past couple of years, there has been a rapid acceleration in the development of a wide range of treatments in which disease-causing genes are replaced in their entirety.

This Outlook therefore focuses on the rich assortment of research in which new genes are introduced into a person, usually by means of a viral vector (see page S18). Successful animal experiments indicate that human genetic disorders could one day be repaired in the womb, so that a baby might enter the world disease-free (S6). And a number of health issues that have proved difficult or impossible to remedy such as sickle-cell disease (S12), epilepsy (S10) and certain intractable skin conditions (S14) - might be excellent targets for gene therapy.

But gene therapy need not be limited to diseases that originate from genetic abnormalities. It might be possible to treat some viral infections with DNA, by using it to prompt the body into creating just the right monoclonal antibodies to ward off invading pathogens (S16).

Gene therapy remains an expensive medical path, however. Moving it out of the laboratory and into the clinic will require innovative pricing schemes (S23) and regulatory policies (S20). Along the way, clinicians, patients and policymakers will grapple with tricky ethical questions (S9).

We are pleased to acknowledge the financial support of Pfizer Inc. in producing this Outlook. As always, Nature has sole responsibility for all editorial content.

\section{Herb Brody \\ Chief supplements editor}

\section{CONTENTS}

\section{S6 NEONATOLOGY}

The fix is in utero

Hereditary diseases healed prenatally

s9 PERSPECTIVE

A genetically augmented future

Ellen Wright Clayton on medical ethics

S10 NEUROLOGY

Repairs for a runaway brain

A way to suppress epileptic seizures

S12 BLOODDISEASE

Medicine is in the blood

Fixing the gene in sickle-cell disease

S14 DERMATOLOGY

Under the skin

Epidermal cells extracted and repaired

S16 IMMUNOLOGY

A genetic shortcut

How to make an antibody factory

S18 THERAPEUTICS

Special delivery

Making viral vectors more efficient

S2O POLICY

Regulating a revolution

Health authorities tackle gene therapy

S23 PERSPECTIVE

Access and affordability for all

Michael Sherman on value-based deals
Nature Outlooks are sponsored supplements that aim to stimulate interest and debate around a subject of interest to the sponsor, while satisfying the editorial values of Nature and our readers' expectations. The boundaries of sponsor involvement are clearly delineated in the Nature Outlook Editorial guidelines available at go.nature.com/e4dwzw

CITING THE OUTLOOK

Cite as a supplement to Nature, for example, Nature Vol. XXX,

No. XXXX Suppl., Sxx-Sxx (2018).

VISIT THE OUTLOOK ONLINE

The Nature Outlook Gene therapy supplement can be found at

www.nature.com/collections/gene-therapy-outlook

It features all newly commissioned content as well as a selection

of relevant previously published material that is made freely available for 6 months.

SUBSCRIPTIONS AND CUSTOMER SERVICES Site licences (www.nature.com/libraries/site_licences): Americas, institutions@natureny.com; Asia-Pacific,http://nature.asia/ jp-contact; Australia/New Zealand, nature@macmillan.com.au; Europe/ROW, institutions@nature.com; India,npgindia@nature. com. Personal subscriptions: UK/Europe/ROW, subscriptions@ nature.com; USA/Canada/Latin America, subscriptions@ us.nature.com; Japan, http://nature.asia/jp-contact; China, http:// nature.asia/china-subscribe; Korea, www.natureasia.com/ko-kr/ subscribe.

CUSTOMER SERVICES

Feedback@nature.com

Copyright $\odot 2018$ Springer Nature Ltd. All rights reserved. 